\title{
EFFECT OF FINANCIAL PERSPECTIVE ON THE PERFORMANCE OF SMALL AND MEDIUM ENTERPRISES
}

\author{
${ }^{1}$ Albert Kiptanui (iD \\ ${ }^{1}$ School of Business, Jomo Kenyatta University of Agriculture and Technology \\ Corresponding author's e-mail: albertkiptanui@gamil.com
}

How to cite this article: Kiptanui, A. (2021). Effect of financial perspective as a determinant of performance in Small and Medium Enterprises. Edith Cowan Journal of Entrepreneurship and Project Management, 1(1), 28-32.

\section{ARTICLE INFO \\ Article history: \\ Received Date: $2^{\text {nd }}$ June 2021 \\ Revised Date: $15^{\text {th }}$ June 2021 \\ Accepted Date: $17^{\text {th }}$ June 2021}

\section{Keywords:}

Strategic plan, organization, performance, SMEs

\section{A B S T R A C T}

Purpose: There are several ways through which business practices can be established in specific areas, which can lead to outstanding business performance. Using balanced scored model, this study looked into the effect of of financial perspective on the Small and Medium Enterprises (SMEs) performance.

Design/ Methodology/Approach: The study was conducted in Elgeyo Marakwet County in Kenya and sampled 95 SMEs using simple random sampling method. First hand data from sampled SMEs was collected using questionnaires and analysed using Ordinal Least Squares (OLS) regression model.

Findings: The study found out that financial perspective had significant influence on SMEs performance $(\beta=0.017, p<0.847)$.

Contribution to policy and practice: The study confirmed the need for the county government and microfinance institutions to support SMEs financial by offering them cheap, affordable and low interest loan to the resident.

Originality/Value: The study extends and contributes to the strategic management literature on factors affecting performance of SMEs. It is the first study to establish financial and customer perspetive as determinants of SMEs performance in Elgeyo Marakwet County in Kenya. 


\section{BACKGROUND}

Financial perspective measures whether the company's strategy, implementation and execution are affecting the bottom line enhancement. Financial goals for big companies are profitability, growth and shareholders' value. But these are different from the financial goals of SMEs who do not have large volume of resources. Kaplan and Norton (1992) observed that SMEs financial goals are simply to continue to exist, to be successful and to prosper. Therefore, they recommended measurement of survival in terms of cash flow, success by quarterly sales growth, operating income by division, prosperity by increased market share by segment, and return on equity.

To date the evidence pertaining to the influence of proactive CSR on a firm's financial performance has been inconclusive. While some studies show no relationship at all (for instance Gilley et al., 2000; Thornton et al., 2003), others have shown a negative relationship (Wagner et al., 2002). However, the majority of studies positively associate proactive financial perspective in large firms with enhanced product differentiation, improved production efficiencies, and lower operation costs, each of which contributes positively to a firm's financial performance (e.g. Harrison and Freeman, 1999; Hart and Ahuja, 1996; Mackey et al., 2007). These mixed findings may be explained in part by the difficulty of demonstrating empirically a clear direct causal effect of financial and customer perspective on financial performance (Burke and Logsdon, 1996; Castka et al., 2004). Furthermore, as proactive building of financial and customer perspective requires a significant investment in resources, the return on that investment may often only be realized in the long-term, rather than becoming immediately apparent through obvious improvement in short-term financial performance (Eisenhardt \& Martin, 2000; Hart \& Ahuja, 1996; Russo \& Fouts, 1997).

Researchers (Lau, Zhao \& Xiao 2004; Prajogo \& Sohal 2003; Rahman \& Sohal 2001) identified a positive relationship between best business practices and business performance. Furthermore, a study by Pushpakumari and Wijewickrama (2008) relating to both large firms and SMEs, constantly emphasizes the relationship between business practices, management activities and firm performance on time of the study. Mandal, Venta and El-Houb (2008) observed that best business practices produce best performance. This study also explains that there are several ways through which business practices can be established in specific areas, which can lead to outstanding business performance.

Measuring performance is a multi-dimensional concept. Effectiveness and efficiency are the two fundamental dimensions of performance; this is emphasized by Neely, Adams et al. (2002) effectiveness refers to the extent to which stakeholder requirements are met, while efficiency is a measure of how economically the firm's resources are utilized when providing a given level of stakeholder satisfaction. To attain superior relative-performance, an organization must achieve its expected objective with greater efficiency and effectiveness than its competitors (Neely 1998). To illustrate efficiency, effectiveness, and the value delivered, multi-measures should be used. Though their forms vary widely, financial indicators are traditionally used; Neely (1998) further expounded upon manufacturing performance measures, suggesting that Performance measurement five key-dimensions should be assessed: quality, delivery speed, delivery reliability, price (cost), and flexibility. By measuring all of these factors, performance is thus balanced and multi-dimensional, better reflecting stockholder interest. Performance is the perfect opportunity to address long-term goals that may not be on the everyday to-do list. Not only does this provide the employee with an opportunity to be of greater use to an organization, the employee feels pleased and valued. Lighting the way toward a successful 
career path inspires loyalty and stability and can improve the bottom line, especially when the employee's first concern is the health of the business, and subsequently, her career. Celebrating a job well-done is the easy part of the performance appraisal. Areas of improvement are not so easy, nevertheless, no one is perfect, and the performance appraisal is an ideal time to diplomatically highlight areas that need improvement. Even the most valuable employee could benefit from additional training, while those who are on the cusp of dismissal need the headsup. When a company has detailed information on employee performance, business decisions become easier. Filling open positions with existing staff strengthens the organization and promotes loyalty. Knowing which employees display what strengths improves the speed with which projects can be assigned. Appraisals also provide a framework when making decisions about compensation and layoffs. If the organization becomes the unfortunate party to a lawsuit, the performance appraisal can refute or support claims. As a result, the effective use of performance appraisals helps an organization operate efficiently and with focus.

The debate over whether a lack of resources constrains the implementation of proactive CSR in SMEs, thus limiting any positive impact on financial performance, remains ongoing (e.g. Gadenne et al., 2008; Miles et al., 1999; Orlitzky, 2001; Rutherfoord et al., 2000; Simpson et al., 2004). However, the idea that there is a positive causal link between proactive CSR and financial performance in SMEs has some empirical support. Financial perspective differs from that of the Traditional private sector. Private sector financial objectives generally represent clear long-range targets for profit-seeking organizations, operating in a purely commercial environment. Financial considerations for public organizations have an enabling or a constraining role, but will rarely be the primary objective for business systems. Success for public organizations should be measured by how effectively and efficiently they meet the needs of their constituencies. Therefore, in the government, the financial perspective emphasizes cost efficiency, i.e., the ability to deliver maximum value to the customer.

$\mathrm{H}_{01}$ : There is no significant relationship between financial perspective and performance

\section{MATERIALS AND METHODS}

The study was carried out among the business persons who live in Elgeyo Marakwet County. The research employed survey research design and according to Sanders and Thorn ill, (2007) is a research that involves data collection from members of a sample for the purpose of estimating one or more population parameters. Survey design is appropriate for this study as it provides description and accounts of business events and objects of research in their natural setting and thus portrays the actual picture. The study targeted Small and Medium Enterprises (SME'S) in Elgeyo/ Marakwet County totaling 2000. The study employed Nassiuma (2000) sample size determination formula to arrive at 95 SMEs. The study adopted stratified sampling and sampling technique where the County was sub divided into 4 sub counties namely; Marakwet East, Marakwet West, Keiyo North and Keiyo South. The simple random Sampling technique will be used to pick respondents from each sub county. Each sub county is expected to generate 22 respondents which will total to 88 and 7 from county Government who will be used as a control totaling to 95 . The study employed correlation and Ordinal Least Squares (OLS) regression to model the relationship between financial perspective and financial performance of SMEs.

\section{RESULTS}


Table 1 Correlation Results

\begin{tabular}{lcc}
\hline \hline & & Financial perspective \\
\hline Financial Perspective & Coefficient & 1 \\
& $\mathrm{~N}$ & 90 \\
Performance (SMEs) & Coefficient & 0.027 \\
\hline & Sig. (2-tailed) & 0.758 \\
\hline & $\mathrm{N}$ & 90 \\
\hline
\end{tabular}

**. Correlation is significant at the 0.01 level (2-tailed).

As shown in Table 1 the financial perspective correlated positively with financial performance of SMEs $(r=0.027, p=0.758)$. However, the correlation was not significant at 0.01 significance level. Table 2 shows regression results.

Table 2 Regression Results

\begin{tabular}{|c|c|c|c|c|c|}
\hline \multirow[b]{2}{*}{ Model } & \multicolumn{2}{|c|}{ Unstandardized Coefficients } & \multicolumn{2}{|c|}{$\begin{array}{l}\text { Standardized } \\
\text { Coefficients }\end{array}$} & \multirow[b]{2}{*}{ Sig. } \\
\hline & B & Std. Error & Beta & $\mathbf{T}$ & \\
\hline (Constant) & 1.087 & .448 & & 2.424 & .017 \\
\hline $\begin{array}{l}\text { Financial } \\
\text { Perspective }\end{array}$ & .026 & .132 & .017 & .193 & .847 \\
\hline
\end{tabular}

\begin{tabular}{lcccc}
\hline Model & $\mathbf{R}$ & R Square & $\begin{array}{c}\text { Adjusted } \mathbf{R} \\
\text { Square }\end{array}$ & Std. Error of the Estimate \\
\hline 1 & $.261^{\text {a }}$ & .068 & .039 & .55874 \\
\hline
\end{tabular}

From the results on model summary $R=0.261, R$ - square $=0.068$, adjusted $R$ - square $=0.039$, and the $\mathrm{SE}=0.55874$. Multiple correlation $\mathrm{R}$ coefficients indicate the degree of linear relationship of performance in SMEs with all the predictor variables, whereas the coefficient of multiple determinations R-square shows the provision of the total variation in performance in Small and Medium Enterprises that is explained by the independent variables, financial perspective ,customer perspective and internal business perspective in the regression equation.

The R-square gives us the coefficient of determination between the variables the results from the regression analysis give an R-square value of 0.068 , which means that $6.8 \%$ of the independent variables cause the change on dependent variable (performance in SMEs).

\section{CONCLUSION}

Financial perspective is a measurement indicator as to whether the company's strategy, implementation and execution are affecting the bottom line enhancement. Kaplan and Norton (1992), for the SMEs, the financial goals are simply to continue to exist, to be successful and to prosper. Though their forms vary widely, financial indicators are traditionally used; Neely (1998) further expounded upon manufacturing performance measures, suggesting that Performance measurement five key-dimensions should be assessed: quality, delivery speed, delivery reliability, price (cost), and flexibility. 
The study concluded that County Government did not support SMEs in giving loans and these retarded their sales growth in SME continuously. This implied that there was no revenue growth, no increased market share in SME, and little increased return on investment in SME. Thus, study recommended the county government and microfinance institutions to support SMEs financial by offering them cheap, affordable and low interest loan to the resident. There is need for SMEs to be educated on the importance of book keeping to facilitate them in value determination for their products, return on capital employed and whether there is increased return on assets in my SME.

\section{REFERENCES}

Aldehayyat and Twaissi, (2011). A performance measurement framework for a small and medium enterprise. Canada, University of Alberta (Canada).

Baker et al, A. and A. Taghavi (2007). "The impacts of acquiring ISO 9000 certification on the performance of SMEs in Tehran." The TQM Magazine 19(2): 140-149.

Beamish, Akinyele and Fasogbon, (2007) "Measuring supply chain performance." International Journal of Operations \& Production Management 19(3).

Cooper \& Schindler. (2006). Research Design: Qualitative and Castrogiovanni, G. J. (1996). Prestartup planning and the survival of new small businesses: Theoretical linkages. Journal of Management, 22(6), pp. 801-822

Cummins et al., (2000"Understanding innovation in small and medium-sized enterprises: a process manifest." Technovation 25(10): 1119-27.

Gilley et al., 2000; Thornton et al., (2003). "Use and impact of performance measurement results in R\&D and NPD: an exploratory study." $R$ \& D Management 34(2): 191.

Hammann et al. (2009) "Performance measurement: implementing strategy", Management Accounting, Vol.72 No.12, pp. $49-53$ for strategy formulation." California Management Review Spring: 114-135.

Kaplan, R. S. and D. P. Norton (2001). The strategy-focused organization: how balanced scorecard companies thrive in the new business environment, Boston, Mass.: Harvard Business School Press, c2001.

Moullin, M. (2003). "Defining Performance Measurement." Perspectives on Performance 2(2): 3.

Neely, A. (1998). "Three models of measurement: theory and practice." International Journal of Business Performance Management 1(1): 47-64.

Norman and Thomas (2003) 'Does Firm Size Confound the Relationship between Social Performance and Firm Financial Performance?', Journal of Business Ethics 33(2), 167180.

Poister, T. H. (2010). The future of strategic planning in the public sector: Linking strategic management and performance. Public Administration Review, December 2010, Special issue.

Srinivasan, R., Woo, C. \& Cooper, A. (1994). 'Performance determinants for male and female entrepreneurs. Frontiers of Entrepreneurship Research', Proceedings of Babson College Entrepreneurship Research Conference, 43-56. 
Tapinos and Jack (2005). Implementing global performance measurement systems

Sturdivant and Ginter (1977) Implementing global performance measurement system a cookbook approach. San Francisco, Jossey-Bass/Pfeiffer.

Tapinos and Jack (2005). Implementing global performance measurement systems.

Teece, David J. (2007). "Explicating Dynamic Capabilities: The Nature and Micro-foundations of (Sustainable) Enterprise Performance, " Strategic Management Journal, 28(13): 13191350.

Trninic, A.H.C., Jardine, A.K.S and Kolodny, H. (1999), "Measuring maintenance performance: a holistic approach", International Journal of Operations \& Production Management, Vol. 19 No. 7, pp. 691-2

Wagner, M., N. Van Phu, T. Azomahou and W. Wherever: 2002, 'the Relationship between the Environmental and Economic Performance of Firms: An Empirical Analysis of the European Paper Industry', Corporate Social Responsibility and Environmental

Wang, C. K. and B. L. Ang (2004). "Determinants of Venture Performance in Singapore*." Journal of Small Business Management 42(4): 347.

Wang, S. D. (2003). The implication of e-financing implication for SMEs. Bulletin on AsiaPacific Perspective, 2003-2004, United Nations.

Williams, S. (1975). Drive Your Business Forward with the Balanced Scorecard, Management Services, (45)6,

Yasin et al. (2004)"A literature review and integrative performance measurement framework for multinational companies." Marketing Intelligence \& Planning 